\title{
Analysis of Transport and Street Addressing Challenges in Oyo State, Nigeria
}

\author{
Somuyiwa Adebambo Olayinka ${ }^{1}$, Adepoju Olusegun Onifade ${ }^{2,}$, Odepidan Omolola Madoh ${ }^{1}$ \\ ${ }^{1}$ Department of Transport Management, Ladoke Akintola University of Technology, Ogbomoso, Nigeria \\ ${ }^{2}$ Department of Maritime Transport, Maritime Academy of Nigeria, Oron, Nigeria
}

Email address:

adeseg001@yahoo.com (A. O. Onifade)

${ }^{*}$ Corresponding author

\section{To cite this article:}

Somuyiwa Adebambo Olayinka, Adepoju Olusegun Onifade, Odepidan Omolola Madoh. Analysis of Transport and Street Addressing Challenges in Oyo State, Nigeria. International Journal of Transportation Engineering and Technology. Special Issue: Emerging Issues in Transport Management, Technology and Integrated Systems for Sustainable Development. Vol. 6, No. 1, 2020, pp. 30-37. doi: $10.11648 /$ j.jitet.20200601.15

Received: February 24, 2020; Accepted: March 12, 2020; Published: April 8, 2020

\begin{abstract}
Proper land use planning system does not only give aesthetic look to an urban area, it also increases accessibility and enhances effective spatial interactions. Mobility in Oyo State, Nigeria has been affected over the years as a result of lack or inaccurate and inadequate street addressing system. The buildings are corrugated without proper delineation therefore making accessibility and mobility extremely difficult. This paper therefore examined the challenges of mobility as a result of haphazard layout of street systems and analyzed the consequences of inadequate or lack of street addresses in the State. Data were collected from town planning officials across the three senatorial districts and commercial drivers from various districts using random, purposive and incidental sampling techniques. Five Local Government Areas were randomly selected from each senatorial district. Descriptive and inferential statistics were used to analyze collected data. The analysis revealed that, 66.9 percent of the variance on the effect of transport could be predicted from the independents variables (Ignorance of Individual; Disagreement over Land; Financial Constraint; Illegal Street Address; Lack of Government Interest; Inadequate Data and Lack of Adherence to Master Plan). Results also indicated that; poor street address has a quantifiable impact on the transport operations, builders did not follow approved city plan, official did not enforce and often there used to be disagreements over ownership of streets in conurbations. It is therefore important for government to enforce strict measures and compliance to street address to avoid confusion and encourage smooth transportation delivery.
\end{abstract}

Keywords: Transport, Street, Challenges and Oyo State

\section{Introduction}

The reports from United Nations [1] noted that, cities compete with each other globally trying to please investors. There is hardly any municipality that does not in its official strategy claim that sustainability is one of its key targets. However, it is a totally different story if one asks into what actions this declaration translates. Transportation is the means by which in our today's world places are reached and locational spatial interactions occur. In other to have well connected and environmentally friendly accessible locations; there is need for land use and futuristic transportation plans. Over the years in Oyo State, Nigeria; there were Acts promulgated to facilitate street addressing systems both at local and state government levels to enhance accessibility and mobility across the state. According to Hansen [2], planners need to understand the difference between mobility and accessibility in order to have sustainable urban and or rural developments. Handy [3] expressed that "policies to increase mobility may generally increase accessibility but having a good accessibility may not lead to good mobility". Her opinion from example provided as illustrated that "a community that usually experience severe congestion but where residents live within a short distance of all needed and desired destinations has poor mobility but good accessibility. Reverse is also possible where there is good mobility but poor accessibility. For instance a community with number of good roads and low level of congestion but relatively 
few destinations for shopping among other required activities has good mobility but poor accessibility. Hence, in order to curb the complexity arising from movement in an environment necessitated street addressing system.

The addressing street challenges arising from land use development plans in which case many allotted portions for a particular land use type are surprisingly used for other. The need to use number or names (dead or alive) in street naming, political influence, illegal building construction, corruption among planning officers, relocation are some of the challenges that inhibit landuse planning and accessible transport systems. According to American Society of Planning Office [4], planning commissions also face difficulties in street naming and house numbering in relation to new subdivisions or new planned neighborhood developments or these problems may arise simply as a result from the difficulties that have come out of the accumulated inefficiencies of an outmoded system.

The well defined transportation landscape provides adequate and accurate addressing systems for poster services, electricity, communication facilities and equipment, pipe borne water system and waste disposal channels. Meanwhile, natural barriers like rivers, mountains, cliff, basins and other man made created railroads tracks do obstruct efficient street naming and house numbering systems. In most cases, inadequate plan or lack of plan creates problem of accessibility for disabled individuals. Another challenge is that, where portion of land are not allocated for buildings, some landowners see it as opportunity and sell the land for unknown persons who are desperate to get land at all costs. The cost of reconstruction of buildings if demolished as most buildings in some part of the state were built when the urban centres were not planned usually hindering proper street naming system.

Consequently, in an attempt to solve these problems; private individual, corporate bodies and government at various levels often offer to create roads especially access roads that will serve as links for easy accessibility. However, there used to be conflicts especially when there is need for demolition of buildings among other structures blocking accessibility and articulated street naming system.

Kolawole et al [5] explained that, GIS-Geographic Information System and Cartography has been used to solve urban street naming and transportation problems. They noted that, the solution to some of the urban street naming and transportation challenges is through mapping system especially in urban area. Street map is a type of map that depicts the locations and names of the streets. The street mapping systems can be useful in planning enumeration areas by demographers; navigation for tourists; salesmen; firemen; police; security agent; tax collectors, postal service etc Ezra and Kantiok [6]. According to Musa and Yusuf [7], the link between transportation and street addresses can provide answers to questions like: Where a road is; where it leads to; the distance and type; the best route between two points or the shortest point. It can also be in form of locating houses and streets, car navigation, planning of transportation, trips and driving directions; and for planning of movement and provision of facilities, goods and services Udoh and Igbokwe [8]. The gap as identified by this paper is the difference between level of existing accessibility in Oyo state and expected level of accessibility in the State.

\section{Review of Relevant Literature and Conceptual Underpinnings}

There is usually rapid economic development and mobility in urban centres due to population growth and necessity for housing accommodations Goldberg [9]. The development or growth as the case may be can be attributed to availability of accessibility through transportation. Okoko [10] pointed out that, there is a quizzical debate as to whether transportation preceded land use or vice versa. According to Oyesiku [11], there will be limited development in the world without means of transportation. The reason is because Little [12] transportation routes especially road transport developed the pattern of a city and form of civilization. Based on the findings of Wyatt [13], urban areas have tendency to develop at nodal points in transport network and places with good road network mostly have advantage over poor road network locations. Then, as a result of good accessibility and connectivity; Singh [14] observed that, there are changes in land value around transport investment or infrastructure. Duranton and Guerra [15] analysed the transport accessibility and mobility with the description of figure 1 below:

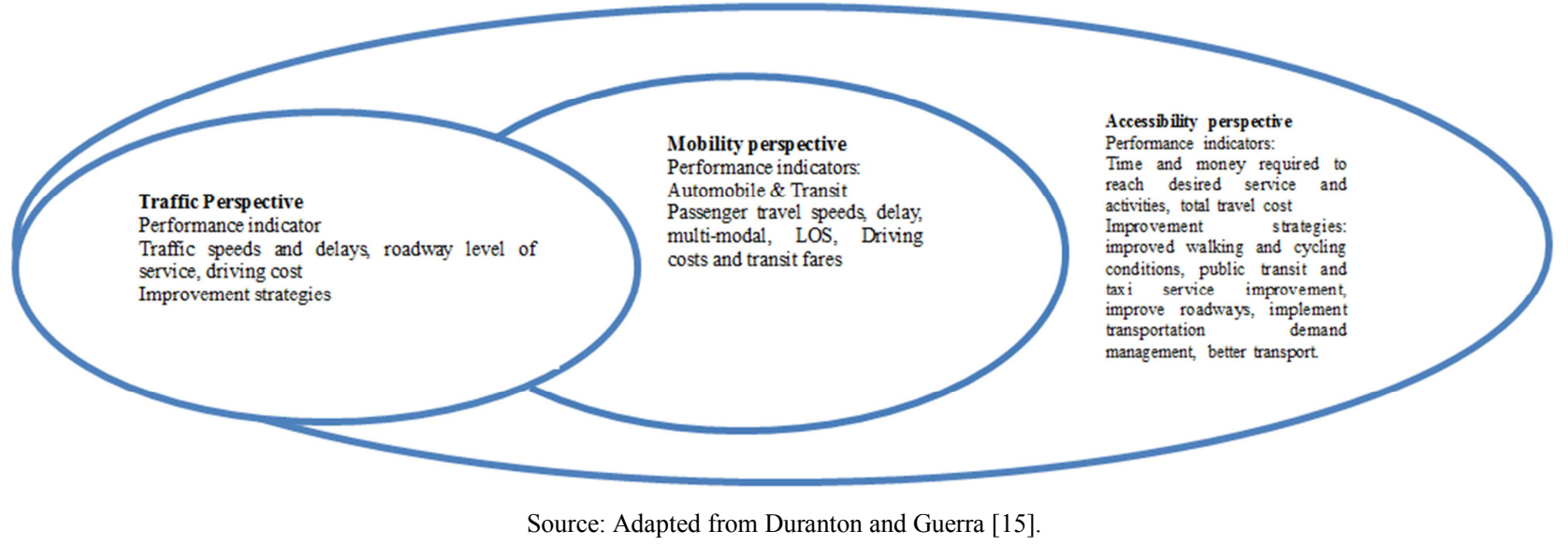

Figure 1. Traffic, Mobility and Accessibility. 
They opined that, vehicle traffic houses mobility which is a subset of accessibility. The interactions among these concepts are fundamental for decision makers and planner as well as for street and house numbering. Even though it has been widely confirmed the relationship between transport and land use system, inadequacy of professionals and manipulation of available ones has been the bane to street naming system in developing economy. Oni [16] observed that, generally the problem of differentiating federal, state and local government roads at time create problems for town planners. There are situations whereby there may be exigent need for the repair, construction and maintenance of some roads to make a residence more accessible but will be neglected due to the fact that it may not fall within the jurisdiction of immediate available tier of government. The problem associated with street addressing system emanated from bidding for land rent where the highest bidder uses the land for whatever that pleases him/her especially in an environment where building and land use act is not in force Kivell [17].

According to Onibokun [18], many Nigerian city centres are decaying without any programme of rehabilitation while new urban peripheries develop without planning or the necessary infrastructure. The harmful effect of this scenario in some places where there were attempts to name street or houses are duplication of names and possibility of legal cases as a result of rivalry over disputes in addressing systems. Another challenge that planners do face may be in terms of naming storey buildings. American Society of Planning Office [4] canvasses for the usage of even and odd numbers to alternate in numbering houses or usage of names, avenue, lane, e. t. c as suffixes in street addressing systems. Kolawole et al [5] noted that, road network helps in creating Street Network Information Management System (SNIMS) which can be used for better administration of the local government area. Paulsson [19] and Vernar et al [20]; Remote Sensing and GIS have been useful in street addressing systems and mapping exercises.

According MDOT [21], street is the primary transportation corridor that supports daily travel, commerce, recreation, activities, and events. Main streets are also a reflection of a community's identity, supporting civic pride and community congregation. Salawu et al [22] stated that, street name forms part of the address while House numbering is the system of giving a unique number to each building in a street or area with the intention of making it easier to locate a particular building. From the analysis of MDOT [21], a well-connected community supports improved access to/from the main street corridor and meets the needs of all users by auto, truck, bus, foot, bicycle, or other assistive device. Main streets also support connections to other major areas of activity, such as employment centers, entertainment, museums, retail centers, and historic districts.

According to Farvacque-Vitkovic et al [23], asked some fundamental questions regarding street naming systems like this: "With no system of street coordinates, how do you find your way around a constantly growing city? How do you dispatch ambulances, firemen, or law enforcement personnel quickly? How do you send mail and messages to private homes? How can municipal services be provided? How do you pinpoint breakdowns in water, electricity, and telephone systems? How do you set up an efficient tax collection system? In spite of the fact that street addressing system eases the challenges of accessibility; human creates problems for and by themselves by parking unscrupulously. According to Asinyanbola and Akinpelu [24], parking becomes a necessity when one recognizes the fact that urban centre are characterized by interrelated and complex land use activities which requires well-planned and efficient performance of the transportation system. On-street parking exists as a result of non-availability of space for off-street parking. Hence, if we say construction of new road is the solution or the expansion of the existing roads, the building of parking lot requires the acquisition of part of the exchange space, the more space allocated to transport, the greater the requirement for more traffic space. Transportation has an insatiable appetite for space, it uses space at home, at work, shopping and even when some spaces are empty, and it is tied up or reserved for the automobile. The use of GIS and mapping system has greatly enhanced the naming of streets. Some decades ago because of the complexities and skillfulness involved in map making can only be executed by surveyors, cartographers and geographers. Kolawole et al [5] stated that, major challenges that industrialization and urbanization had brought are the complexities of urban transportation system and inability to monitor the fast increase in new streets and structures. United Nations [1] observed that, globalization and financialization have direct impacts which resulted in the changes in our urban landscape and shaped more by global political and economic decisions than by the seemingly more visible results of local urban planners. Redefining of ecosystem for sustainability as a result of climate change draws the attention of authorities at various levels and disrupting the existing system. There are so many people who preferred their houses being called with a prefix of 'gidan' and their various names (i.e. literarily 'house of') [22]. The disputes that used to arise from street naming system according to a report from New Jersey indicated that, it lie mostly on legislative acts and not judicial although subject to review by or interference from the courts.

Problems of street addressing may confront planning commissions in relation to new subdivisions or new planned neighborhood developments or these problems may arise simply as a result from the difficulties that have come out of the accumulated inefficiencies of an outmoded system. No one would advocate designing a city or a subdivision along certain lines merely because it would be easy for the visitor or the delivery truck to locate persons and buildings. A wellplanned community, with well-grouped major uses and service facilities, and with efficient means of intercommunication, is the primary concern of planners. However, once a street plan has been adopted by a community, with major and minor streets laid out, with feeder streets, and residential streets, and through highways and heavy traffic bearers, designed each according to its function, facilitating the use of these streets follows naturally. 
Effective street addressing can be hindered due to funds not being available to do necessary documentation. As important as this is and its effect on transport, there are lots of arguments why it is believed that it is not necessary.

General Arguments for Adopting a Street Address System

Many arguments may be advanced to justify the need for special funds for a study of existing practices in a community, or to justify street address reorganization ordinance has been presented below:

1. Unfavorable impression on visitors to the community if they have difficulty in finding places of interest and the businesses and persons they wish to see.

2. Expense to delivery services in routing and rerouting packages.

3. Difficulty in quick delivery of mail.

4. Loss of letters and goods, wrongly addressed.

5. Potential increase in traffic accidents by motorists intent on searching for correct address rather than on driving.

6. Difficulty in training civic employees in knowledge of the city, and the resultant disappointment by residents and visitors in the caliber of these employees and the government in general.

7. Subconscious feeling of estrangement toward community on the part of residents and visitors to the community.

8. Difficulty in maintaining correct legal documents, such as those for licenses, vital statistics, deeds.

The Gravity Model

The gravity model is the most common formulation of the spatial interaction method. It is named as such because it uses a similar formulation than Newton's law of gravity. Gravity like representations have been applied in a wide variety of contexts, such as migration, commodity flows, traffic flows, commuting, and evaluating boundaries between market areas. Accordingly, the attraction between two objects is proportional to their mass and inversely proportional to their respective distance. Consequently, the general formulation of spatial interactions can be adapted to reflect this basic assumption to form the elementary formulation of the gravity model: $\mathrm{T}_{\mathrm{ij}}=\mathrm{K} \mathrm{P}_{\mathrm{i}} \mathrm{P}_{\mathrm{j}}$

$\mathrm{d}_{\mathrm{ij}}$

i. $\quad P_{i}$ and $P_{j}$ : Importance of the location of origin and the location of destination.

ii. $d_{i j}$ : Distance between the location of origin and then location of destination.

iii. $k$ is a proportionality constant related to the rate of the event. For instance, if the same system of spatial interactions is considered, the value of $k$ will be higher if interactions were considered for a year comparatively to the value of $k$ for one week.

Thus, spatial interactions between locations $i$ and $j$ are proportional to their respective importance divided by their distance.

$\mathrm{T}_{\mathrm{ij}}=\mathrm{K} \mathrm{P}_{\mathrm{i}} \mathrm{P}_{\mathrm{j}}$

$\mathrm{d}_{\mathrm{ij}}$

The gravity model can be extended to include several calibration parameters:

i. $P, d$ and $\mathrm{k}$ refers to the variables previously discussed.

ii. $\beta$ (beta): A parameter of transport friction related to the efficiency of the transport system between two locations. This friction is rarely linear as the further the movement the greater the friction of distance. For instance, two locations services by a highway will have a lower beta index than if they were serviced by a road.

iii. $\lambda$ (lambda): Potential to generate movements (emissivity). For movements of people, lambda is often related to an overall level of welfare. For instance, it is logical to infer that for retailing flows, a location having higher income levels will generate more movements.

iv. $\alpha$ (alpha): Potential to attract movements (attractiveness). Related to the nature of economic activities at the destination. For instance, a center having important commercial activities will attract more movements.

Spatial Interaction

The spatial interaction is a dynamic flow process from one location to another. It is a general concept that may refer to the movement of human beings such as intra urban commuters or intercontinental migrants, but may also refer to traffic in goods such as raw materials or to flows of intangibles such as information. Spatial interactions cover a wide variety of movements such as journeys to work, migrations, tourism, the usage of public facilities, the transmission of information or capital, the market areas of retailing activities, international trade and freight distribution. These movements can be physical (people or freight) or intangible (information). Economic activities are generating (supply) and attracting (demand) flows. The simple fact that a movement occurs between an origin and a destination underlines that the costs incurred by a spatial interaction are lower than the benefits derived from such an interaction. As such, a commuter is willing to drive one hour because this interaction is linked to an income, while international trade concepts, such as comparative advantages, underline the benefits of specialization and the ensuing generation of trade flows between distant locations. There are three interdependent conditions that are necessary for this interaction to take place meaningfully. They include:

i. Complementarily: Connotes that, there must be a supply and a demand between the interacting locations. A residential zone is complementary to an industrial zone because the first is supplying workers while the second is supplying jobs.

ii. Intervening opportunity: This gives access to alternatives from inception to the final destination. It is an avenue for interaction where closed group of products are not closed by

iii. Transferability: In this case, freight, persons or information being transferred must be supported by transport infrastructures, implying that the origin and the destination must be linked. Costs to overcome distance must not be higher than the benefits of related interaction, even if there is complementarily and no alternative opportunity [25]

Through spatial interaction, transport resources stands a better chance of allocation because it will reflect the actual demand of transport be it the buses, aircrafts, ships and intermodal transport. 
The measure of flow is predictable and the changes that causes them. In Spatial Interaction Models, the basic assumption concerning many spatial interaction models is that flows are a function of the attributes of the locations of origin, the attributes of the locations of destination and the friction or relationships of distance between the concerned origins and the destinations. The general formulation of the spatial interaction model is as follows: $\mathrm{T}_{\mathrm{ij}}=\mathrm{f}\left(\mathrm{V}_{\mathrm{i}}, \mathrm{W}_{\mathrm{j}}, \mathrm{S}_{\mathrm{ij}}\right)$

This function is explained as follows:

i. $T_{i j}$ : Interaction between location $i$ (origin) and location $j$ (destination). Its units of measurement are varied and can involve people, tons of freight, traffic volume, etc. It also relates to a time period such as interactions by the hour, day, month, or year.

ii. $V_{i}$ : Attributes of the location of origin i. Variables often used to express these attributes are socio-economic in nature, such as population, number of jobs available, income, industrial output or gross domestic product.

iii. $W_{j}$ : Attributes of the location of destination $\mathrm{j}$. It uses similar socio-economic variables than the previous attribute.

iv. $S_{i j}$ : Attributes of separation between the location of origin $i$ and the location of destination $j$. Also known as transport friction. Variables often used to express these attributes are distance, transport costs, or travel time.

\section{Methodology}

Oyo State as the case study for this research is an inland
State in South-western Nigeria, and has its capital at Ibadan. It shares boundary with the north by Kwara State, in the east by Osun State, in the south by Ogun State and in the west partly by Ogun State and partly by the Republic of Benin. It was created 3rd February, 1976 with total population of 5,580,894 population according to the 2006 census with Coordinates: $8^{\circ} 00^{\prime} \mathrm{N}, 4^{\circ} 00^{\prime} \mathrm{E}$. Oyo State covers approximately an area of 28,454 square kilometers and is ranked 14 th by size. The landscape consists of old hard rocks and dome shaped hills, which rise gently from about 500 meters in the southern part and reaching a height of about 1,219 metre above sea level in the northern part. Oyo State's Climate is equatorial, notably with dry and wet seasons with relatively high humidity. The dry season lasts from November to March while the wet season starts from April and ends in October. Average daily temperature ranges between $25^{\circ} \mathrm{C}\left(77.0^{\circ} \mathrm{F}\right)$ and $35^{\circ} \mathrm{C}\left(95.0^{\circ} \mathrm{F}\right)$, almost throughout the year. The major occupation in this region is Agricultural farming but development it is tending towards industrialization.

Oyo state contains thirty-three (33) Local governments with three (3) senatorial districts (see figure 2). Five Local Government Areas were randomly selected from each senatorial district. There are lots of households across the selected area and we purposively sampled 50 household respondents across the selected Area with accidental sampling of 50 commercial drivers and motorcyclists. The returned questionnaires were analyzed using descriptive and inferential statistics.

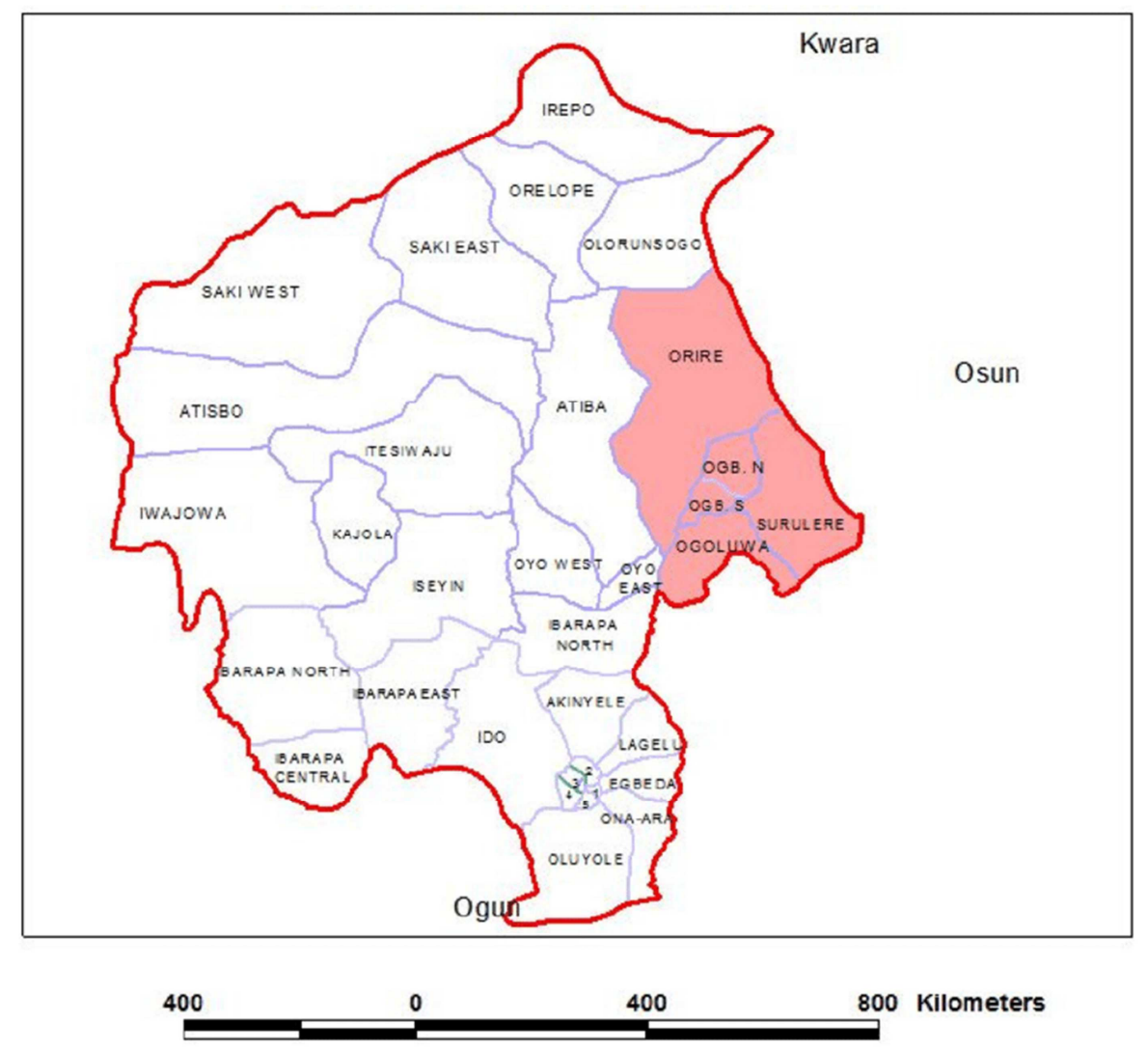

Source: Authors' adapted map (2017).

Figure 2. Map of Oyo State Local Government showing the senatorial districts. 
Table 1. Names of areas where Questionnaire were administered.

\begin{tabular}{ll}
\hline Local Government Area & Location \\
\hline Iseyin & Iseyin \\
Ogbomoso North & Ajaawa \\
Ogomoso South & Arowomole \\
Surulere & Iresaadu \\
Saki East & Ago Amodu \\
Olorunsogo & Igbeti \\
Atisbo & Tede \\
Ibadan North & Agodi Gate \\
Akinyele & Moniya \\
Oluyole & Idi Ayunre \\
Ibadan South West & Ring Road \\
Ona Ara & Igboho \\
Egbeda & Egbeda \\
Lagelu & Iyana offa \\
Ibarapa East & Eruwa \\
\hline
\end{tabular}

Source: Authors Field Survey, (2019).

\section{Results and Discussion}

Street addressing includes allocation of numbers, street names to service roads connecting traffic from residential area to the main road network of an area. Challenges arises when this names cannot be identified and located with ease by transport operators, this pose a great challenge to effective transportation and interaction with business environment.

\subsection{Socio Economic Characteristics of the Respondents}

\subsubsection{Sex of the Respondents}

Table 2. Shows that most of the respondents were male.

\begin{tabular}{lll}
\hline Sex & Town Planning Officials & Commercial Drivers \\
\hline Male & $75 \%$ & $90 \%$ \\
Female & $25 \%$ & $10 \%$ \\
Total & $100 \%$ & $100 \%$ \\
\hline
\end{tabular}

Source: field Survey, (2019).

\subsubsection{Age Distribution Among Respondents}

Table 3 shows that majority of the respondents were within the age bracket of 21-50. It implies that they are adults and do have good understanding of any situation and events happening around them.

Table 3. Age bracket of the respondents.

\begin{tabular}{lll}
\hline Age & Town Planning Officials & Commercial Drivers \\
\hline$<20$ & $2 \%$ & - \\
$21-30$ & $17 \%$ & $19 \%$ \\
$31-40$ & $45 \%$ & $36 \%$ \\
$41-50$ & $24 \%$ & $37 \%$ \\
50 and Above & $12 \%$ & $8 \%$ \\
Total & $100 \%$ & $100 \%$ \\
\hline
\end{tabular}

Source: Field Survey, 2019.

\subsubsection{Marital Status of Respondents}

Table 4 shows that most of the respondents are married therefore show a level of responsibility.
Table 4. Marital Status of the respondents.

\begin{tabular}{lll}
\hline Marital Status & Town Planning Officials & Commercial Drivers \\
\hline Single & $25 \%$ & $36.5 \%$ \\
Married & $60 \%$ & $55 \%$ \\
Others & $15 \%$ & $8.5 \%$ \\
Total & $100 \%$ & $100 \%$ \\
\hline
\end{tabular}

Source: Field survey (2019).

\subsubsection{Level of Education of Respondents}

Table 5 shows that majority of the town planning officials are graduates with minimum of a OND while the commercial drivers are secondary school leaver.

Table 5. Academic qualifications of the respondents.

\begin{tabular}{lll}
\hline Educational Status & $\begin{array}{l}\text { Town Planning } \\
\text { Officials }\end{array}$ & $\begin{array}{l}\text { Commercial } \\
\text { Drivers }\end{array}$ \\
\hline Primary & - & $6 \%$ \\
Secondary & $35 \%$ & $67 \%$ \\
Polytechnic Graduate (OND) & $37 \%$ & $20 \%$ \\
University Graduate (first degree) & $18 \%$ & - \\
Others & $10 \%$ & $7 \%$ \\
Total & $100 \%$ & $100 \%$ \\
\hline
\end{tabular}

Source: Field Source (2019).

\subsection{Street Numbering Responsibilities}

Table 6 shows that both government and individuals were involved in street addressing but the government contribute more.

Table 6. Shared responsibility of addressing system.

\begin{tabular}{lll}
\hline $\begin{array}{l}\text { Street Address } \\
\text { Responsibility }\end{array}$ & $\begin{array}{l}\text { Town Planning } \\
\text { Officials }\end{array}$ & Commercial Drivers \\
\hline Government & $67 \%$ & $100 \%$ \\
Individuals & $33 \%$ & - \\
Total & $100 \%$ & $100 \%$ \\
\hline
\end{tabular}

Source: Field Source (2019).

\subsection{Available Street Address}

Table 7 shows the observed street address against the total number of streets in the study area. It was established that due to inadequate and correct addresses on street, transport operators find it difficult to deliver goods in a just in time manner. In tandem to this, online delivery by third party logistics was inadequate in the study area. As a result of this economic development is inadequate.

Table 7. Available Street Address.

\begin{tabular}{llll}
\hline $\begin{array}{l}\text { Local Government } \\
\text { Area }\end{array}$ & Location & $\begin{array}{l}\text { Observed street } \\
\text { address }\end{array}$ & $\begin{array}{l}\text { Expected } \\
\text { street address }\end{array}$ \\
\hline Iseyin & Iseyin & 35 & 150 \\
Ogbomoso North & Ajaawa & 100 & 200 \\
Ogomoso South & Arowomole & 50 & 250 \\
Surulere & Iresaadu & 15 & 80 \\
Saki East & Ago Amodu & 27 & 79 \\
Olorunsogo & Igbeti & 48 & 150 \\
Atisbo & Tede & 35 & 190 \\
Ibadan North & Agodi Gate & 76 & 150 \\
\hline
\end{tabular}




\begin{tabular}{llll}
\hline $\begin{array}{l}\text { Local Government } \\
\text { Area }\end{array}$ & Location & $\begin{array}{l}\text { Observed street } \\
\text { address }\end{array}$ & $\begin{array}{l}\text { Expected } \\
\text { street address }\end{array}$ \\
\hline Akinyele & Moniya & 58 & 180 \\
Oluyole & Idi Ayunre & 60 & 150 \\
Ibadan South West & Ring Road & 100 & 200 \\
Ona Ara & Igboho & 37 & 130 \\
Egbeda & Egbeda & 28 & 140 \\
Lagelu & Iyana offa & 40 & 100 \\
Ibarapa East & Eruwa & 60 & 150 \\
\hline
\end{tabular}

Source: Author's Field survey, (2019).

Table 8 presents the analysis of street addressing system challenges with the use of Chi-square analysis.

Table 8. Chi-Square Analysis.

\begin{tabular}{lllll}
\hline $\begin{array}{l}\text { Observed street } \\
\text { address Oij }\end{array}$ & $\begin{array}{l}\text { Expected street } \\
\text { address Eij }\end{array}$ & $\begin{array}{l}\mathbf{O} \mathbf{i j}- \\
\mathbf{E i j}\end{array}$ & \begin{tabular}{l}
$\mathbf{( O i j ~}-_{\mathbf{E i j}}{ }^{2}$ \\
\hline 35
\end{tabular} & $\frac{(\mathbf{O i j}-\mathbf{E i j})^{2}}{\text { Eij }}$ \\
\hline 150 & 200 & -115 & 13228 & 5.753 \\
50 & 250 & -100 & 10000 & 4.350 \\
15 & 80 & -200 & 40000 & 17.397 \\
27 & 79 & -75 & 5625 & 2.447 \\
48 & 150 & -52 & 2704 & 1.176 \\
35 & 190 & -102 & 10404 & 4.525 \\
76 & 150 & -155 & 24025 & 10.450 \\
58 & 180 & -74 & 5476 & 2.382 \\
60 & 150 & -122 & 14884 & 6.474 \\
100 & 200 & -90 & 8100 & 3.523 \\
37 & 130 & -100 & 10000 & 4.350 \\
28 & 140 & -93 & 8649 & 3.762 \\
40 & 100 & -112 & 12544 & 5.456 \\
60 & 150 & -60 & 3600 & 1.566 \\
& 2299 & -90 & 8100 & 3.523 \\
\hline & & & & 77.134 \\
\hline
\end{tabular}

$$
X^{2}=\frac{(\mathrm{Oij}-\mathrm{Eij})^{2}}{\mathrm{Eij}}=77.134
$$

Df $=\mathrm{n}-1=15-1=14$

Chi square table value at $5 \%$ level of significance at Df $14=23.685$

Calculated value $=77.134$

The result shows that street addressing is inadequate and this poses a great challenge to effective transport operations.

\subsection{Street Address Challenges on Transport}

Tables 9, 10 and 11 show the relationship between the challenges of street address and its effect on transport operations. The primary dependent variable is defined as effect on transport while the independent variables are defined as Ignorance of Individual; Disagreement over Land; Financial Constraint; Illegal Street Address; Lack of Government Interest; Inadequate Data and Lack of Adherence to Master Plan.

$\mathrm{R}$ is 0.828 this implies the combined effect that the independent variables have on the dependent variable. Adjusted $\mathrm{R}^{2}$ is 0.669 . This implies that 66.9 percent of the variance on the effect of transport could be predicted from the independent variables attributed to, accounted for and explained by variance in the set of predicator variable taken as a whole. The table also shows that the analysis of variance for the multiple regression data produced F-ratio of 44.099 which is significant at $\mathrm{P}<0.05$, this implies that all the regression parameters are significantly different from zero.

Table 9. Model Summary.

\begin{tabular}{lllll}
\hline Model Summary & & & & \\
\hline Model & R & R Square & Adjusted R Square & Std. Error of the Estimate \\
\hline 1 & $.828^{\mathrm{a}}$ & .685 & .669 & .905 \\
\hline
\end{tabular}

Table 10. Anova result

\begin{tabular}{lllllll}
\hline ANOVA $^{\mathbf{b}}$ & & & & & \\
\hline Model & & Sum of Squares & df & Mean Square & F & Sig. \\
\hline \multirow{3}{*}{1} & Regression & 252.968 & 7 & 36.138 & 44.099 & $.000^{\mathrm{a}}$ \\
& Residual & 116.366 & 142 & .819 & & \\
& Total & 369.333 & 149 & & \\
\hline
\end{tabular}

a. Predictors: (Constant), ignorance of individual, disagreement over land, financial constraint, ilegal street address, lack of government interest, inadequate data, lack of adherence to master plan.

b. Dependent Variable: effect on transport.

Table 11. Coefficient Results.

\begin{tabular}{|c|c|c|c|c|c|c|}
\hline \multicolumn{7}{|c|}{ Coefficients $^{\mathrm{a}}$} \\
\hline \multirow{2}{*}{ Model } & & \multicolumn{2}{|c|}{ Unstandardized Coefficients } & \multirow{2}{*}{$\begin{array}{l}\text { Standardized Coefficients } \\
\text { Beta }\end{array}$} & \multirow[b]{2}{*}{$\mathbf{t}$} & \multirow{2}{*}{ Sig. } \\
\hline & & B & Std. Error & & & \\
\hline \multirow{8}{*}{1} & (Constant) & 3.793 & .600 & & 6.320 & .000 \\
\hline & disagreement over land & -.871 & .082 & -.573 & -10.657 & .000 \\
\hline & illegal street address & 1.560 & .156 & .546 & 10.006 & .000 \\
\hline & financial constraint & -.848 & .156 & -.264 & -5.429 & .000 \\
\hline & lack of government interest & -.119 & .088 & -.072 & -1.356 & .177 \\
\hline & inadequate data & .263 & .068 & .216 & 3.839 & .000 \\
\hline & lack of adherence to master plan & .164 & .101 & .122 & 1.627 & .106 \\
\hline & ignorance of individual & .171 & .099 & .131 & 1.730 & .086 \\
\hline
\end{tabular}

a. Dependent Variable: effect on transport. 


\section{Conclusion and Recommendation}

From the result of the test, it was deduced that poor street address has a quantifiable impact on the transport operations. It also shows that builders did not follow approved city plan, official did not enforce and often there used to be disagreements over ownership of streets in a conurbation. It is therefore important for government to enforce strict measures and compliance to street address to avoid confusion and encourage smooth transportation service delivery. Though the autonomy has been given to individuals to name a street, government should always embark on routine checks in order to see to the adherence of the right given. Adequate data should also be kept for street addresses as it is done for any registration such as the voters' card, driving license, national identity card etc.

\section{References}

[1] United Nations (2012): Challenges and way forward in the urban sector Sustainable Development in the 21st century (SD21)

[2] Hansen, W. G. 1959. How Accessibility Shapes Land Use. Journal of the American Planning Institute, Vol. 25, pp. 73-76.

[3] Handy Susan (2002): Accessibility- vs. Mobility-enhancing strategies for addressing automobile dependence in the U.S. Department of Environmental Science and Policy University of California at Davis Davis, CA 95616 slhandy@ucdavis.edu.

[4] American Society of Planning Office 2017: www.planning.org/conference/future-previous New York.

[5] Kolawole, I. S., Alaga, T. A., Ogunyemi, S. A., Popoola, O. S. and Oloko-Oba, M. O. (2016) Street Mapping of Ife Metropolis, Osun State, Nigeria. Journal of Geographic Information System, 8, 387-395. http://dx.doi.org/10.4236/jgis.2016.83033.

[6] Ezra, P. H. and Kantiok, L. (2007) The Relevance of Maps in the Control of Urban Slums. Proceedings of the 29th Annual Conference of NCA, Kaduna, August 2007, 21-25.

[7] Musa, D. and Yusuf, R. K. (2007) Geographic Information System (GIS): A Tool for Land Resources Management in Nigeria. Proceedings of the 29th Annual Conference of NCA, Kaduna, August 2007, 10-15.

[8] Udoh, I. B. and Igbokwe, J. I. (2014) Production of Revised Street Map of Uyo Urban Area, Nigeria Using Remote Sensing and GIS Approach. International Journal of Engineering Research and Technology, 3, 1792-1799.

[9] Goldberg, M. A. (1970): Transportation, Urban Land Values, and Rents: A Synthesis Land Economics, 46, 2 (May), 153162.
[10] Okoko Eno (2006): Urban Transportation Planning and Modelling by Millenium Publishers, Akure.

[11] Oyesiku, O. O. (2002). From Womb to Tomb. 24th Inaugural Lecture at Olabisi Onabanjo University on 27 August 2002. Ago-Iwoye: Olabisi Onabanjo University Press.

[12] Little, A. (2008): The Broader Connection between Public Transportation, Energy Conservation and Greenhouse Gas Reduction. Report prepared as part of TCRP Project J-11/ Task 3 TransitCooperative Research Program, Transportation Research Board submittedto American Public Transportation Association inhttp://www.apta.com/research/info/online/land_use.cfm\#i, accessed 17.

[13] Wyatt, P. (1997). The Development of a GIS-Based Property Information for Real Estate Valuation. International Journal of Information Science 11 (5), 435-450.

[14] Singh, S. K. (2005). Review of Urban Transportation in India. Journal of Public Transportation, 8, 1.

[15] Duranton Gilles and Guerra Erick (2016), Developing a Common Narrative on Urban Accessibility: An Urban Planning Perspective, Brookings Institution (www.brookings.edu); at www.brookings.edu/wpcontent/uploads/2017/01/landusage-digital.pdf.

[16] Oni, A. O. (2008): An Empirical Study of the Lagos State Rent Edict of 1997. Journal of the Nigerian Institution of Estate Surveyors and Valuers. 31, 1, January - June, 2008, 20-32.

[17] Kivell, P. (1993). Land and The City. London: Routledge.

[18] Onibokun A. G (1987): Public Utilities and Social Services in Nigerian Urban Centres: Problems and guides for action. IDRC, Canada and NISER, Ibadan.

[19] Paulsson, B. (1992) SPOT Data for Urban Land-Cover Mapping and Road Map Revision. International Achieves of Photogrammetry and Remote Sensing, 29. 352-357.

[20] Vernar, R. K., Kumari, S. and Tiwary, R. K. (2008) Application of Remote Sensing and GIS Technique for Efficient Urban Planning in India. Paper Presented at Geomatrix 2008.

[21] MDOT (2006): - Michigan Department of TransportationGuidance for Trunk line Main Streets.

[22] Salawu O. A, Angbo, Y. B and Abuga E. A (2014): Lafia: a State Capital without Street Names and House NumbersWorld J Building Technology, and Estate Management 2014; 1 (1): 10.

[23] Farvacque-Vitkovic C, Godin L, LerouxH, Verdet F, Chavez R. Street Addressing and The Management of Cities. 2014. Retrieved.

[24] Asinyanbola R. A and Akinpelu A. A (2012): The challenges of on-street parking in Nigerian Cities' transportation routes International Journal of Development and Sustainability Online ISSN: 2186-8662 www.isdsnet.com/ijdsfrom:http://citiesalliance.org/sites/citiesa 1liance.org/files/CA Images/Street Addressing Manual.pdf. 